\title{
TUTTI FRATELLI? PERSPECTIVES AND CHALLENGES FOR INTERNATIONAL HUMANITARIAN LAW
}

\author{
KJ Keith*
}

This article is based on addresses given in The Hague, Wellington and Auckland in 2009 to mark the 150th anniversary of the beginnings of the International Red Cross and Red Crescent Movement. Out of a dreadful day of war, the Battle of Solferino, was born a great humanitarian institution.

In late June 1859, a young Swiss banker journeyed to Castiglione in northern Italy. He wished to discuss with Napoleon III his plans for major agricultural developments in Algeria. Instead, he came upon the dreadful carnage of the battle that had just ended at nearby Solferino between Napoleon III's troops, supported by the Sardinians, and the Austrians led by the young Emperor Franz Joseph. After just one day, there were between 30,000 and 40,000 casualties. It was the most destructive day of battle since Waterloo.

The response of Henry Dunant was both immediate and long term. He organised the relief of the injured, and, for several days, he was himself wholly immersed in that effort. And he promoted through constant effort, including his writing (particularly the haunting A Memory of Solferino $^{1}$ ) and much travel, first, the establishment in 1863 of the organisation which became the International Committee of the Red Cross (ICRC), ${ }^{2}$ second, the statement of legal commitment, incorporated in

* Judge, International Court of Justice; Professor Emeritus and Distinguished Fellow, Victoria University of Wellington; International Humanitarian Law Consultant to the New Zealand Red Cross Society. I drew on papers given in Canberra in 1983 and Duke University on 4 February 1997. Michael Meyer provided most valuable comments and corrections!

1 J Henry Dunant Un Souvenir de Solférino (Imprimerie Jules-Guillaume Fick, Geneva, 1862). The quotations appearing in this article are taken from the English version, A Memory of Solferino, published by the American Red Cross in 1939 and reprinted by the International Committee of the Red Cross (ICRC) by courtesy of the American Red Cross in 1986.

2 In 1863 the International Committee for the Relief of Military Wounded was created and from 1876 it was known as the ICRC. 
the first Geneva Convention of 1864 for the Amelioration of the Condition of the Wounded in Armies in the Field, ${ }^{3}$ and, third, the promotion of the application of that law and the use of national relief organisations on the battlefield.

Seven matters at least stand out from those early years. The first is simple humanity. Dunant puts this graphically in many passages of his Memory. One passage reads as follows: ${ }^{4}$

The moral sense of the importance of human life; the humane desire to lighten a little the torments of all these poor wretches, or restore their shattered courage; the furious and relentless activity which a man summons up at such moments: all these combine to create a kind of energy which gives one a positive craving to relieve as many as one can.

The principle of humanity appears in Article 5 of the very first Convention: ${ }^{5}$

Generals of the belligerent Powers shall make it their duty to notify the inhabitants of the appeal made to their humanity, and of the neutrality which humane conduct will confer.

Closely connected, my second point is the principle of non-discrimination, the proposition that "we are all brothers". In Dunant's words: ${ }^{6}$

... the women of Castiglione, seeing that I made no distinction between nationalities, followed my example, showing the same kindness to all these men whose origins were so different, and all of whom were foreigners to them. "Tutti fratelli", they repeated feelingly. All honour to these compassionate women, to these girls of Castiglione! Imperturbable, unwearying, unfaltering, their quiet self-sacrifice made little of fatigue and horrors, and of their own devotion.

And that principle too is reflected in the Convention, in Article 6: "[w]ounded or sick combatants, to whatever nation they may belong, shall be collected and cared for."7

That provision, to emphasise a third point, imposes a positive obligation: the wounded and sick shall be collected and cared for. Further, those engaging in those humanitarian activities in ambulances, hospitals and evacuation parties or as local inhabitants bringing help are all to be protected and respected and recognised as neutrals.

3 Convention for the Amelioration of the Condition of the Wounded in Armies in the Field (adopted 22 August 1864, entered into force 22 June 1865).

4 Dunant, above n 1, at 73.

5 Convention for the Amelioration of the Condition of the Wounded in Armies in the Field, above n 3, art 5.

6 Dunant, above n 1 , at 72.

7 Convention for the Amelioration of the Condition of the Wounded in Armies in the Field, above n 3 , art 6 (emphasis added). 
Those three points combine to make a fourth - about the rights and responsibilities of the individuals involved in warfare, as combatant or victim. It is individuals who are to apply the law, and to respect humanitarian principles for the benefit of individuals.

The drafting and ratification of the provisions of the 1864 Convention make a fifth point which again may be seen as a response to Dunant's plea: ${ }^{8}$

On certain special occasions, as, for example, when princes of the military art belonging to different nationalities meet at Cologne or Chậlons, would it not be desirable that they should take advantage of this sort of congress to formulate some international principle, sanctioned by a Convention inviolate in character, which, once agreed upon and ratified, might constitute the basis for societies for the relief of the wounded in the different European countries?

He stressed the importance of getting agreement in advance of the beginning of hostilities.

You will have noticed, to come to the sixth point I draw from those early years, that Dunant anticipated the establishing of national societies for the relief of the wounded, a matter which was addressed in the Conference in Geneva in 1863. Those societies were first mentioned in the 1906 revision of the 1864 Convention. ${ }^{9}$ Henry Dunant had again proposed that these be set up in advance of hostilities: ${ }^{10}$

Would it not be possible, in time of peace and quiet, to form relief societies for the purpose of having care given to the wounded in wartime by zealous, devoted and thoroughly qualified volunteers?

With his colleagues in the Committee of Five, notably Gustave Moynier, ${ }^{11}$ he anticipated the need to promote that proposal, a task which they undertook over the following years with the consequence that there are now 186 National Societies.

As a seventh and final point, may I stress the simple as well as the humanitarian character of the law as stated in 1864, closely based on a draft prepared by Moynier. It covers barely a page and consists of just ten articles. In its modern form it is lengthy and detailed - hundreds of pages of it. But for many purposes it is possible to keep it simple. That appears from the excellent statement, attached to this article, entitled the Fundamental Rules of International Humanitarian Law Applicable in Armed Conflict prepared in 1978 by a small group of experts covered by the ICRC. ${ }^{12}$

8 Dunant, above n 1 , at 126 ,

9 Convention for the Amelioration of the Condition of the Wounded and Sick in Armies in the Field (opened for signature on 6 July 1906, entered into force 9 August 1907).

10 Dunant, above $\mathrm{n} 1$, at 115.

11 See Jean de Senarclens The Founding of the Red Cross: Gustave Moynier, its Master Builder (Slatkine, Geneva, 2005).

12 ICRC "Fundamental Rules of International Humanitarian Law Applicable in Armed Conflicts" reprinted in (1978) 206 IRRC 247 at 248-249. See Appendix. 
The seven rules fit into a single page. Similar statements may be found in the pocket cards issued to armed forces and in their rules of engagement. Those for Desert Storm in 1991 for instance extended to nine rules and were followed by this summary: ${ }^{13}$

Remember

1. Fight only combatants

2. Attack only military targets

3. Spare civilian persons and objects

4. Restrict destruction to what your mission requires

To emphasise the points about humanity and simplicity, could I take you back to 1864, the year of the first Convention, but away from the conference room to an actual battle.

I take you to the other side of the world, to New Zealand and the Battle of Gate Pā, a battle between 250 Ngai Te Rangi warriors, a local tribe, and nearly 2000 British soldiers, a battle won by the 250. Before the battle, the Māori chief despatched to the British commanding officer "the solemn rules for governing the fighting". Their laws for regulating the fight were four in total: ${ }^{14}$

Rule 1. If wounded or (captured) whole, and butt of the musket or hilt of the sword be turned to me (he) will be saved.

Rule 2. If any Pakeha being a soldier by name, shall be travelling unarmed and meet me, he will be captured, and handed over to the direction of the law.

Rule 3. The soldier who flees, being carried away by his fears, and goes to the house of the priest with his gun (even though carrying arms) will be saved; I will not go there.

Rule 4. The unarmed Pakehas, women and children will be spared.

That instance provides some evidence of the universality of the values and principles we are concerned with, values and principles which had also been recognised a year earlier in much greater detail in General Orders 100 prepared by Francis Lieber and issued by President Lincoln for the armies of the North. ${ }^{15}$

I have mentioned Dunant's call for the preparation of law in advance of the hostilities. The history of the development of the law over the past 150 years shows that the world community has

13 A Roberts and R Guelff (eds) Documents on the Laws of War (3rd ed, Oxford University Press, New York, 2000) at 562

14 Gilbert Mair The Story of Gate Pa April 29th, 1864 (Bay of Plenty Times, Tauranga, 1937) at 20.

15 Reproduced in D Schindler and J Toman (eds) The Laws of Armed Conflict: A Collection of Conventions, Resolutions and Other Documents (4th ed, Martinus Nijhoff Publishers, Leiden, 2004) 3. 
generally not had sufficient foresight or political willingness to do that. Rather, it has usually, but not always, written the law after the event: in 1929, to give greater protection to prisoners of war; ${ }^{16}$ in 1949 , to give basic protections to civilians especially in occupied territory (that conference tragically had not been able to take place in 1940, as planned); ${ }^{17}$ in 1977, first, to update the 1899 and 1907 Hague Treaties on the law governing the conduct of hostilities, particularly to provide for the protection of civilians from bombardment in the light of developments, especially technological, over the course of the 20th century; second, to elaborate the law relating to non-international armed conflicts beyond Common Article 3 of the 1949 Conventions, the so called mini-convention of 1949 ; and, third, to strengthen the methods of implementation and enforcement of the law. ${ }^{18}$

I will come to those matters of implementation and enforcement later, for obviously with the carnage, often involving apparent or alleged breaches of IHL, occurring around the world, I must do that. But first, I would mention two aspects of the stability of this body of law - the legal and the political.

On the legal aspect, the law operates completely autonomously and independently of the lawfulness or justness of the resort to armed force. All 194 State parties undertake to respect and to ensure respect for the Conventions in all circumstances. ${ }^{19}$ Next, the parties are not able by agreement to vary their obligations if that would affect the rights of those protected, nor can those protected waive their rights. ${ }^{20}$ It is clear law as well that a breach by one party does not release another party of its obligations. ${ }^{21}$ And while States are free to withdraw from the Conventions -

16 Convention relative to the Treatment of Prisoners of War (opened for signature 27 July 1929, entered into force 19 June 1931).

17 See Convention (I) for the Amelioration of the Condition of the Wounded and Sick in Armed Forces in the Field (opened for signature 12 August 1949, entered into force 21 October 1950); Convention (II) for the Amelioration of the Condition of Wounded, Sick and Shipwrecked Members of Armed Forces at Sea (opened for signature 12 August 1949, entered into force 21 October 1950); Convention (III) relative to the Treatment of Prisoners of War (opened for signature 12 August 1949, entered into force 21 October 1950); Convention (IV) relative to the Protection of Civilian Persons in Time of War (opened for signature 12 August 1949, entered into force 21 October 1950) [Geneva Conventions]. See also Geneva Conventions Act 1958, schs 1-4.

18 Protocol Additional to the Geneva Conventions of 12 August 1949, and relating to the Protection of Victims of International Armed Conflicts (Protocol I) (opened for signature 8 June 1977, entered into force 7 December 1978) [Additional Protocol I]; Protocol Additional to the Geneva Conventions of 12 August 1949, and relating to the Protection of Victims of Non-International Armed Conflicts (Protocol II) (opened for signature 8 June 1977, entered into force 7 December 1978). See also Geneva Conventions Amendment Act 1987, schs 5-6.

19 See Geneva Conventions, above n 17, art 1. See also Geneva Conventions Act 1958, schs 1-4, art 1.

20 See Geneva Conventions I-III, above n 17, arts 6-7; Geneva Convention IV, above n 17, arts 7-8. See also Geneva Conventions Act 1958, schs 1-3, arts 6-7 and sch 4, arts 7-8.

21 Vienna Convention on the Law of Treaties (opened for signature 23 May 1969, entered into force 27 January 1980), art 60(5) 
something that has never happened in fact - their withdrawal does not take effect until peace has been concluded and operations relating to protected persons are complete; moreover, the withdrawal in no way impairs the obligations arising by virtue of the principles of the law of nations, as they result from the usages established among civilised peoples, from the laws of humanity and from the dictates of the public conscience - the words of Frederic de Martens, a great Russian diplomat, which helped resolve a major impasse at the 1899 Hague Peace Conference. ${ }^{22}$

That may be the legal basis for the stability of this body of law, but what is to be made, in terms of its political stability, of attacks on parts of the Geneva law, beginning early in 2002, as "quaint" and "obsolete" and as not applicable to aspects of the conduct of the so called "war on terror". ${ }^{23}$ I do not enter into the substance of those contentions. I simply mention what happened in the following years within the context of the International Red Cross and Red Crescent Movement. Among the actions were the continuing work under the auspices of the ICRC on the customary law study and the Harvard-Swiss high-level informal meetings. In the course of 2003, the ICRC organised a series of five very important regional seminars on the content of the Geneva law and its better implementation, especially in internal armed conflicts. At the end of 2003, in its regular four yearly schedule, the 28th International Conference of the Red Cross and Red Crescent met. That Conference is one of the biggest regular international meetings. It consists of about 400 delegations - from the State parties to the Conventions (now 194), the national societies (now 186), the ICRC and the International Federation of Red Cross and Red Crescent Societies, along with the observers. The Conference, with all members, State or non State, having an equal vote, unanimously adopted a Declaration entitled "Protecting human dignity". For me, a critical sentence is one that reads: ${ }^{24}$

Convinced that the existing provisions of international humanitarian law form an adequate basis to meet challenges raised by modern armed conflicts, we solemnly urge all parties to an armed conflict to respect all applicable treaties and rules of customary international law.

This Declaration, essentially repeated in 2007 , provides very strong support for the existing state of the law. One change in the 2003 draft emphasises that support: it included the phrase "in

22 See Geneva Convention I, above n 17, art 63; Geneva Convention II, above n 17, art 62; Geneva Convention III, above n 17, art 142; Geneva Convention IV, above n 17, art 158. See also Geneva Conventions Act 1958, sch 1, art 63, sch 2, art 62, sch 3, art 142 and sch 4, art 158.

23 Memo from Alberto Gonzales to President Bush (25 January 2002), reprinted in Mark Danner Torture and Truth: America, Abu Ghraib, and the War on Terror (New York Review Books, New York, 2004) at 83. In fairness to the author, the adjectives, especially "quaint", do need to be read in context.

24 ICRC "Resolutions of the International Conference: 28th International Conference of the Red Cross and Red Crescent, Geneva, 2-6 December 2003" (2003) 852 IRRC 885 at 889-890. 
general" - the existing law in general forms an adequate basis, but that qualifier was deleted. The Conference participants also recalled: ${ }^{25}$

... the protections granted by international humanitarian law to persons captured in connection with an armed conflict. All detainees must be treated with humanity and with respect for their inherent dignity. The inherent dignity of every human being can best be promoted and safeguarded through a complementary application of, in particular, international humanitarian law, human rights law and refugee law, as appropriate. International humanitarian law is not an obstacle to justice, and it requires that all persons alleged to have committed crimes be granted due process of law and fair trial. Moreover, we affirm that no State, no group or individual is above the law and no one should be considered or treated as beyond its reach.

I now come to the huge challenge of implementation, again emphasised in the 2007 International Conference and at the International Humanitarian Law Conference held in Wellington in August 2007 of 150 delegates from Commonwealth countries and national societies and highlighted every day in the media. A wide array of national and international methods is available. Some have been available for centuries. Others are new. What too often is missing is the commitment to using them.

Many of you will be very familiar with particular methods. I may be allowed to look at the matter rather broadly and to provide some context. Let me mention some variables. The methods are national and international; they may be used before, during and after the conflict; they may be directed at a party to the conflict or at individuals; they may involve persuasion or coercion; they may involve fact finding, good offices, mediation, arbitration or adjudication; they may be limited to the armed forces or directed more generally to schools and tertiary institutions and the public at large; they may involve public processes or be carried out in confidence; they may be permanent or ad hoc; they may present difficult choices between justice and peace; they may face major practical problems of operation. You will be able to align particular methods against those matters and especially against the reluctance of States to make use of the available methods. I would stress the last. That all too frequent reluctance may be matched against the rhetoric and urging of the International Conferences and the General Assembly of the United Nations in its two yearly resolutions. ${ }^{26}$ I recall in my own mind the various failed attempts we made when I was a member of the International Humanitarian Fact-Finding Commission elected under the First Additional Protocol of 1977 to get parties to a conflict to refer allegations to it. ${ }^{27}$

25 Ibid.

26 See Status of the Protocols Additional to the Geneva Conventions of 1949 and relating to the protection of victims of armed conflicts GA Res 63/125, A/RES/63/125 (2008) and the 30th International Conference of Red Cross and Red Crescent Resolution 3 (26-30 November 2007).

27 Additional Protocol I, above n 18, art 90. 
Out of all the methods I mention aspects of two. One I touched on earlier with the story of Gate Pā. Education and training programmes, both for the armed forces and more generally, can be made more real by drawing on national stories - or indeed any well known story as Professor (now Judge) Meron has done in his excellent studies of Shakespeare and the law of war. ${ }^{28}$ I will mention more stories later.

The other method I mention is the unremitting independent work of the ICRC in seeking to get better compliance with the law, in general, through confidential negotiations with governments and other relevant groups and, in times of war, with all parties to the conflict: when should they break that basic obligation of confidentiality?

Jakob Kellenberger, the President of the ICRC, made a valuable contribution to this issue in $2004^{29}$ and that was followed last year by the ICRC's Deputy Director of Operations. ${ }^{30}$ You will have noticed ICRC statements relating to particular conflicts in recent weeks and days. You might relate them to existing doctrine and earlier practice. The Deputy Director indicates interesting limits on its general obligation of confidentiality, for instance: ${ }^{31}$

... if a detaining authority issues excerpts from one of our confidential reports - without our consent we reserve the right to publish the entire report in order to prevent any inaccurate or incomplete interpretations of our observations and recommendations.

Similarly, if, after repeated requests, prisoners continue to be mistreated or if we are prevented from working according to our recognised operating procedures, we may suspend detainee visits or our operations and publicly explain the reasons.

If it's clear that our confidential approach isn't working - for example, because a government or rebel group simply refuses to take our concerns seriously, and that we've exhausted all other avenues of discourse, we can and will take action by expressing our concerns publicly. The decision to speak out is never taken lightly but it's important to remember that confidentiality is not unconditional.

We should not focus only on the formal institutional means aimed at compliance and implementation. Also critical are wider forces and values supporting compliance. You may like to

28 See for example T Meron Henry's Wars and Shakespeare's Laws: Perspectives on the Law of War in the Later Middle Ages (Oxford University Press, New York, 1993).

29 Jakob Kellenberger "Speaking Out or Remaining Silent in Humanitarian Work" (2004) 855 IRRC 593.

30 Interview with Dominik Stillhart, ICRC's Deputy Director of Operations (ICRC, 3 June 2008), available as "Confidentiality: key to the ICRC's work but not unconditional" at <www.icrc.org $>$.

31 Ibid 
relate what I am about to say to what to me seem very wise words of John Keegan, a great military historian, at the end of his A History of Warfare: ${ }^{32}$

There is a wisdom in the principles of intellectual restraint and even of symbolic ritual that needs to be rediscovered. There is an even greater wisdom in the denial that politics and war belong with the same continuum.

For my first wider force or value, I am back with Henry Dunant, Gate Pā and humanity. George Orwell, fighting in the Spanish Civil War, refrained from shooting a man who jumped from a ditch: ${ }^{33}$

He was half-dressed and was holding up his trousers with both hands as he ran. ... I did not shoot partly because of that detail about the trousers. I had come here to shoot at "Fascists"; but a man who is holding up his trousers isn't a "Fascist", he is visibly a fellow-creature, similar to yourself, and you don't feel like shooting at him.

A related force or reason is military tradition. It was that tradition that weighed with Admiral Canaris of the German Navy when, in September 1941, he protested against the regulations for the treatment of Soviet prisoners of war. For him, the fact that the Soviet Union had not ratified the 1929 Convention $^{34}$ was not decisive: ${ }^{35}$

[T]he principles of general international law on the treatment of prisoners of war apply. Since the 18 th century these have gradually been established along the lines that war captivity is neither revenge nor punishment, but solely protective custody, the only purpose of which is to prevent the prisoners of war from further participation in the war. This principle was developed in accordance with the view held by all armies that it is contrary to military tradition to kill or injure helpless people ...

According to the Nuremberg Tribunal, this protest correctly stated the legal position. ${ }^{36}$

Compliance with the law might also promote military efficiency and military advantage. Napoleon once remarked that nothing would disorganise an army more or ruin it more completely than pillaging. ${ }^{37}$ And Lord Blackett, a leading British physicist, made this comment about the area

32 J Keegan A History of Warfare (Knopf, New York, 1993) at 392.

33 George Orwell "Looking Back on the Spanish War" in George Orwell: A Collection of Essays (Harcourt Brace Jovanovich, New York, 1954) 193, quoted in M Walzer Just and Unjust Wars (Basic Books, New York, 1977) at 140.

34 Convention relative to the Treatment of Prisoners of War, above n 16

35 Trial of the Major War Criminals before the International Military Tribunal Nuremberg 14 November 1945-1 October 1946 (International Military Tribunal, Nuremberg, 1947) vol I at 232.

36 Ibid

37 Comments of Gordon Baldwin in "Panel Discussion: Compliance During Hostilities" (1964) 58 ASIL PROC 82 at $91-92$. 
bombing in World War II: "the area bombing, which was originally adopted just because of the inability to do precision bombing, did little to help win the war and greatly increased our difficulties afterwards." 38

Winston Churchill, near the end of World War II, made Blackett's point very forcibly and added an economic consideration. In a minute prepared just after the bombing of Dresden that was directed to the Chiefs of Staff Committee and the Chief of Air Staff and which, in its first form, had referred to the "bombing of German cities simply for the sake of increasing the terror", ${ }^{39}$ he declared: ${ }^{40}$

It seems to me that the moment has come when the question of so called "area bombing" of German cities should be reviewed from the point of view of our own interests. If we come into control of an entirely ruined land, there will be a great shortage of accommodation for ourselves and our Allies.

My final story is my earliest, from an event the night before the Battle of Agincourt in 1415. Following Ted Meron, I draw on Shakespeare's account of what happened to Bardolph, who was to be executed for robbing a church. Henry $\mathrm{V}$, in confirming the execution, repeated the essence of the law of the time and added a critical political or moral reason for compliance. This is what, according to Shakespeare, he said: ${ }^{41}$

We would have all such offenders cut off. And we give express charge that, in our marches through the country, there be nothing compelled from the villages, nothing taken but paid for, none of the French upbraided or abused in disdainful language; for when lenity and cruelty play for a kingdom, the gentler gamester is the soonest winner.

Individual responsibility, with the most serious sanctions attached in the event of a serious breach by an individual, is now very much to the fore with the development, over the last 60 years and especially the last 25, of the law and institutions of international criminal law. I may mention Nuremberg, Tokyo, Yugoslavia, Rwanda, Sierra Leone, East Timor and Cambodia and now the permanent International Criminal Court. That denial of impunity may well have an important deterrent effect. ${ }^{42}$

We must confront and try to defeat the proposition that law disappears in the face of war by emphasising the values on which the law is based, law and values which reflect as well, I should

38 Quoted in Hans Blix "Area Bombardments: Rules and Reasons" (1978) 49 BYIL 31 at 60-61.

39 Charles Webster and Noble Frankland The Strategic Air Offensive against Germany 1939-1945 (HMSO, London, 1961) vol 3 at 112 .

40 Ibid, at 117.

41 William Shakespeare Henry the Fifth Act III, Sc 6.

42 I am grateful to Beat Nobs, Swiss Ambassador to New Zealand, for emphasising this point when I spoke in Wellington. 
add, the demands of military necessity which appears expressly in certain provisions of the Geneva law and which is worked throughout the substance of law. The limit implicit in military necessity is available only when the treaty provides for it. ${ }^{43}$ In that respect, it is important to recall the processes for the drafting and adoption of the international texts and the participants in that process, including many experienced members of their countries' armed forces. This law is not the product of theory alone. It arises from harsh experiences of the realities of warfare.

What more can be done to get greater compliance and reduce the horrors of armed conflict? One answer is provided by a point stressed at the outset. It is the responsibility of individuals, of each of us, to do what we can by thought, word and action. Think of Henry V, Napoleon, Henry Dunant, Francis Lieber, Henare Taratoa, the young warrior who wrote the 1864 solemn rules for Gate Pā, and, to conjure with another name from 150 years ago, Charles Darwin.

In the one case, Darwin's observation of many facts over decades led to a revolutionary theory an amazing feat of thinking by one man. In Dunant's case, the observation of the facts of the horrors of just one day led again to a great set of ideas and actions. ${ }^{44}$ In each case, the working out of the ideas, the law, the institutions, has continued ever since. In the case of those following Dunant's Dream, ${ }^{45}$ the commitment is to the protection and promotion of humanity in the midst of armed conflict through the principles, rules and institutions of international humanitarian law.

43 See for example G Draper The Red Cross Conventions (Praeger, New York, 1958) at 96-97.

44 The formulation in the text probably states the 1859 contrast too sharply since Henry Dunant was already affected by the ideas of the Enlightenment and of liberty; from early in his life he was engaged in visiting the poor and sick and prisoners and he was a founder of what became the YMCA. See for example "The Liberty Century" in A Grayling Towards the Light: The Story of the Struggles for Liberty and Rights that Made the Modern West (Bloomsbury, London, 2007) 217.

45 The title of an excellent book by Caroline Moorehead: Caroline Moorehead Dunant's Dream: War, Switzerland and the History of the Red Cross (HarperCollins, London, 1998). 


\section{APPENDIX}

1978 Red Cross Fundamental Rules of International Humanitarian Law Applicable in Armed Conflicts

1. Persons hors de combat and those who do not take a direct part in hostilities are entitled to respect for their lives and physical and moral integrity. They shall in all circumstances be protected and treated humanely without any adverse distinction.

2. It is forbidden to kill or injure an enemy who surrenders or who is hors de combat.

3. The wounded and sick shall be collected and cared for by the party to the conflict which has them in its power. Protection also covers medical personnel, establishments, transports and materiel. The emblem of the red cross (red crescent, red lion and sun) is the sign of such protection and must be respected.

4. Captured combatants and civilians under the authority of an adverse party are entitled to respect for their lives, dignity, personal rights and convictions. They shall be protected against all acts of violence and reprisals. They shall have the right to correspond with their families and to receive relief.

5. Everyone shall be entitled to benefit from fundamental judicial guarantees. No one shall be held responsible for an act he has not committed. No one shall be subjected to physical or mental torture, corporal punishment or cruel or degrading treatment.

6. Parties to a conflict and members of their armed forces do not have an unlimited choice of methods and means of warfare. It is prohibited to employ weapons or methods of warfare of a nature to cause unnecessary losses or excessive suffering.

7. Parties to a conflict shall at all times distinguish between the civilian population and combatants in order to spare civilian population and property. Neither the civilian population as such nor civilian persons shall be the object of attack. Attacks shall be directed solely against military objectives. 